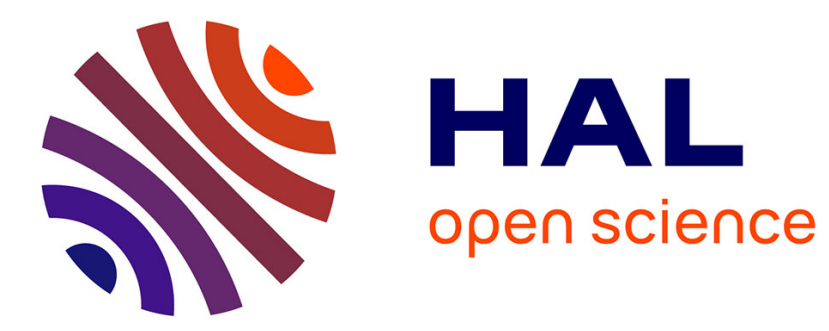

\title{
Experimental identification of the overall elastic rigidities of superconducting windings
}

René Rotinat, Raphaël Moulart, François Nunio, Pierre Vedrine

\section{To cite this version:}

René Rotinat, Raphaël Moulart, François Nunio, Pierre Vedrine. Experimental identification of the overall elastic rigidities of superconducting windings. ISEM 2015, 2015, Kobe, Japan. pp.1-2. hal01178164

\section{HAL Id: hal-01178164 \\ https://hal.science/hal-01178164}

Submitted on 28 Aug 2015

HAL is a multi-disciplinary open access archive for the deposit and dissemination of scientific research documents, whether they are published or not. The documents may come from teaching and research institutions in France or abroad, or from public or private research centers.
L'archive ouverte pluridisciplinaire HAL, est destinée au dépôt et à la diffusion de documents scientifiques de niveau recherche, publiés ou non, émanant des établissements d'enseignement et de recherche français ou étrangers, des laboratoires publics ou privés. 


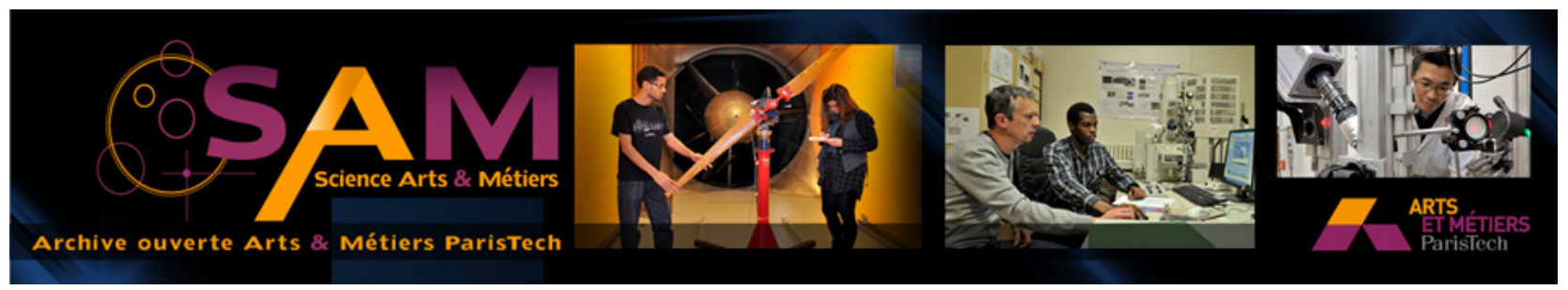

Science Arts \& Métiers (SAM)

is an open access repository that collects the work of Arts et Métiers ParisTech researchers and makes it freely available over the web where possible.

This is an author-deposited version published in: http://sam.ensam.eu

Handle ID: .http://hdl.handle.net/10985/9814

\section{To cite this version :}

René ROTINAT, Raphaël MOULART, François NUNIO, Pierre VEDRINE - Experimental identification of the overall elastic rigidities of superconducting windings - In: ISEM 2015, Japon, 2015 - ISEM 2015 - 2015 


\title{
Experimental identification of the overall elastic rigidities of superconducting windings
}

\author{
René ROTINAT, Raphaël MOULART \\ MSMP lab., Arts et Métiers ParisTech, Rue St Dominique, 51006, Châlons-en-Champagne, France \\ François NUNIO, Pierre VEDRINE \\ DSM/IRFU/SIS/LCAP, CEA, Bâtiment 123, 91191, Gif-sur-Yvette, France
}

\begin{abstract}
This study deals with of the experimental methodology developed in order to identify the elastic properties of superconducting ring-shaped windings. Mechanical tensile tests were conducted on specimens associated to a full-field displacement measurement technique. Strain fields were then obtained from the measured displacement fields by numerical differentiation. Finally, the four inplane orthotropic stiffnesses of the windings were determined using the Virtual Fields Method.
\end{abstract}

\section{Introduction}

The objective of the French-German project Iseult/INUMAC is to developed a whole-body 11.7 $\mathrm{T}$ magnetic resonance imaging (MRI) to improve sensitivity, spatial, temporal and spectral resolution for preclinical and clinical MR systems [1]. The main coil winding is a stack of double pancakes (DP) composed of two layers connected through a transition area (Figure 1).

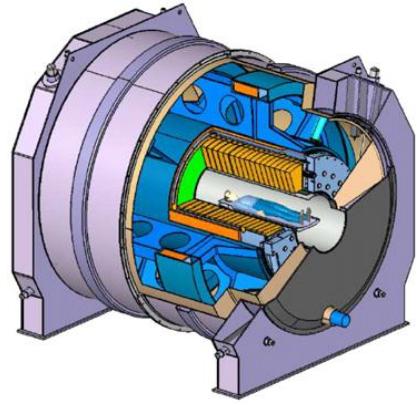

(a)

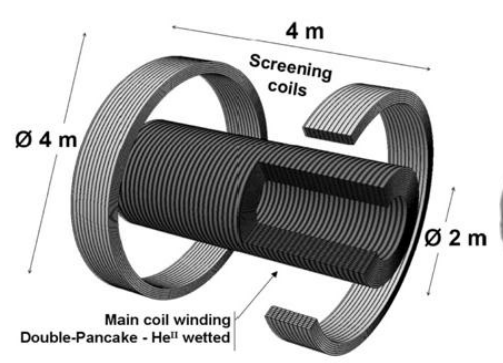

(b)

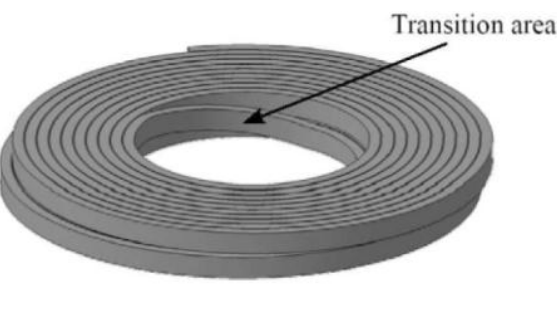

(c)

Fig. 1 Iseult 11.7 T MRI (a) magnet assembly (b) magnetic circuit and (c) geometry of the double pancake

Copper/NbTi cable-in-channel-type conductor is wound in $2 \times 88$ turns in each DP and insulation fiberglass-epoxy composite tape bonds the conductors together. A fiberglass-epoxy composite plate is inserted between the two coil layers for insulation, and an additional fiberglass-epoxy composite plate is attached on the inner diameter area of the DP. The objective is to identify equivalent elastic orthotropic stiffness components for this complex structure.

The mechanical properties of coil winding are usually obtained from mechanical tests using local measurement techniques [2]. However, these techniques are poorly suited to the anisotropic case study. Consequently, a suited inverse approach associated with full-field kinematic measurement has been set up. In a previous works, a general methodology based on the use of the virtual field method (VFM) to identify rigidities of thick laminated composite tubes has been firstly developed [3] then applied to a reduced scale DP (2×20 turns winding) [4]. In this study, the methodology is now applied on a real scale DP.

\section{Methodology}

The mechanical test on DP is a diametrical tensile test, i.e. an actuator applies a force in two points of the inner radius of the DP leading to a mixed tensile-bending state of stress. The experimental set-up is illustrated in Figure 2. A set of six CCD cameras (three for each side), has 
been used to measure the deformation of the DP on both sides at the same time by digital image correlation technique (DIC). In each side of DP, two cameras follow in-plane and out-of-plane displacement of a partial DP area (a disk sector of around $30^{\circ}$ ) in order to extract rigidities and a third camera is used to track occurrence of delamination on the entire side.
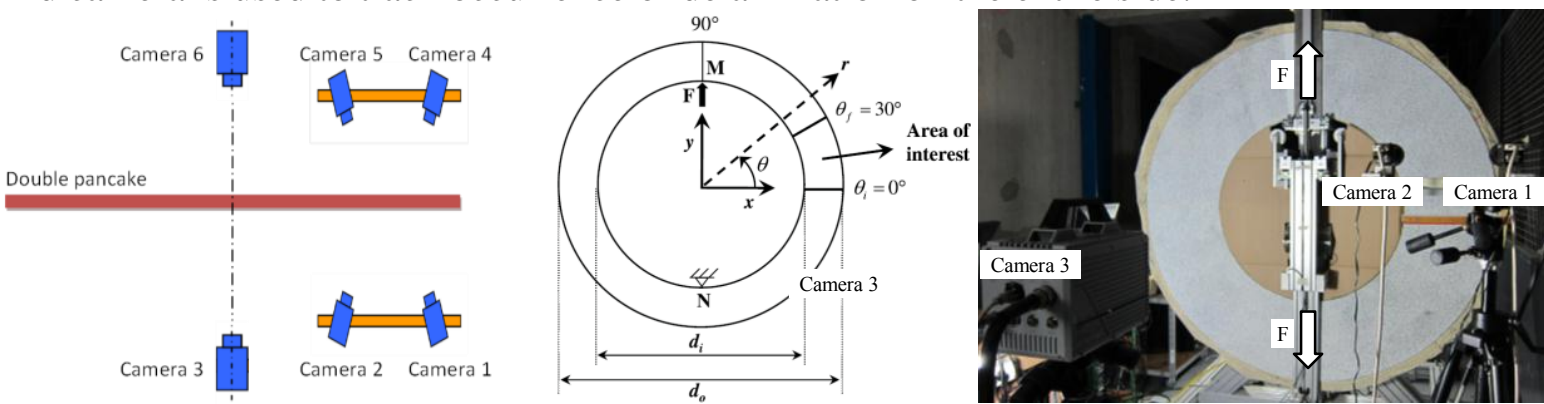

Fig. 2 Experimental set-up

To use the DIC, it was necessary to paint a speckle pattern on both faces of the DP at the same level. The experimental implementation was performed using VIC3D stereo-correlation software and the camera calibration was conducted for each face measurement [5]. The preliminary study [4] has proven that, due to the complex structure of the windings, out-of-plane bending occur when submitted to the diametral tension and that it is necessary for a correct identification of stiffnesses to cancel it by averaging strain fields from both sides of the DP. These average strain fields are then computed by VFM technique which describes the global equilibrium of the solid [3]. The average identified values are listed in Table 1 . The identification of $\mathrm{E}_{\theta \theta}, \mathrm{G}_{\mathrm{ss}}$ and $v_{\theta \mathrm{r}}$ is reasonably stable. A larger spread is observed in $\mathrm{E}_{\mathrm{rr}}$ because this rigidity is related to the radial strain which is very low. Nevertheless, by considering a basic rule of mixtures, it can be to define reference stiffness values (Table 1) from the expected properties of each component (superconductor, insulation tape) and it was observed that experimental results are in good agreement with these reference values.

\begin{tabular}{lcc}
\hline Rigidities & Identified & Reference \\
\hline $\mathrm{E}_{\mathrm{rr}}(\mathrm{GPa})$ & 86.7 & 82 \\
$\mathrm{E}_{\theta \theta}(\mathrm{GPa})$ & 116.7 & 115 \\
$\mathrm{G}_{\mathrm{ss}}(\mathrm{GPa})$ & 21.3 & 29 \\
$\mathrm{v}_{\theta \mathrm{r}}$ & 0.38 & 0.36 \\
\hline
\end{tabular}

Table 1 Identified and reference stiffness components for DP

\section{Conclusion}

In conclusion, the methodology associating a non-contact full-field measurement and an inverse procedure (VFM) to process strain field allows to identify the overall elastic rigidities of the real scale DP forming the main coil winding. The set-up developed also allows to control in the same time the appearance of delamination cracks.

\section{References}

[1] P. Vedrine et al, Iseult/INUMAC Whole body 11.7 T MRI Magnet Status, IEEE Trans. Appl. Supercond. 18 (2008) 868-873.

[2] I. R. Dixon et al, Mechanical properties of epoxy impregnated superconducting solenoids, IEEE Trans. Magn. 32 (1996) 2917-2920.

[3] R. Moulart et al, Identification of the through-thickness rigidities of a thick laminated composite tube, Composite A 37 (2006) 326-336.

[4] J.-H. Kim et al, Characterizing elastic properties of superconducting windings by simulations and experiments, Supercond. Sci. Technol. 24 (2011) 125001 (15pp).

[5] F. Amiot et al, Assessment of Digital Image Correlation Measurement Accuracy in the Ultimate Error Regime: Main Results of a Collaborative Benchmark, Strain 49 (2013) 483-496. 